\title{
A Journey to the Conformational Analysis of T-Cell Epitope Peptides Involved in Multiple Sclerosis
}

\author{
Catherine Koukoulitsa ${ }^{1}$, Eleni Chontzopoulou ${ }^{1}$, Sofia Kiriakidi ${ }^{1}$, Andreas G. Tzakos ${ }^{2}$ (I) \\ and Thomas Mavromoustakos ${ }^{1, *(1)}$ \\ 1 Department of Chemistry, National and Kapodistrian University of Athens, Zographou, 15784 Athens, \\ Greece; ckoukoulitsa@chem.uoa.gr (C.K.); elenichontzo@chem.uoa.gr (E.C.); sofki@chem.uoa.gr (S.K.) \\ 2 Department of Chemistry, Section of Organic Chemistry and Biochemistry, University of Ioannina, \\ 45110e Ioannina, Greece; atzakos@uoi.gr \\ * Correspondence: tmavrom@chem.uoa.gr; Tel.: +30-210-7274475
}

Received: 13 May 2020; Accepted: 2 June 2020; Published: 8 June 2020

\begin{abstract}
Multiple sclerosis (MS) is a serious central nervous system (CNS) disease responsible for disability problems and deterioration of the quality of life. Several approaches have been applied to medications entering the market to treat this disease. However, no effective therapy currently exists, and the available drugs simply ameliorate the destructive disability effects of the disease. In this review article, we report on the efforts that have been conducted towards establishing the conformational properties of wild-type myelin basic protein (MBP), myelin proteolipid protein (PLP), myelin oligodendrocyte glycoprotein (MOG) epitopes or altered peptide ligands (ALPs). These efforts have led to the aim of discovering some non-peptide mimetics possessing considerable activity against the disease. These efforts have contributed also to unveiling the molecular basis of the molecular interactions implicated in the trimolecular complex, T-cell receptor (TCR)-peptide-major histocompatibility complex (MHC) or human leucocyte antigen (HLA).
\end{abstract}

Keywords: conformational analysis; peptides; altered peptide ligands; multiple sclerosis; MS; NMR spectroscopy; NOE-constraints; molecular dynamic; trimolecular complex; experimental autoimmune encephalomyelitis

\section{Introduction}

Multiple sclerosis (MS) is a serious disease of the central nervous system (CNS). MS affects almost 3.3 million people worldwide [1]. It affects more females than males between the ages of 20 and 40 [2]. MS-related disability significantly affects the quality of life (e.g., restraints on daily life activities) [3]. As the number of patients continuously increases, negative effects on social and economic aspects have been observed $[4,5]$. Factors such as genetic, environment, metabolism and viral infections considerably progress the disease [6,7].

MS is classified into four subclasses according to the increase of the neurologic deterioration of the disease:

1. Relapsing-remitting MS (RRMS): This is the most frequently occurring and affects ca. $85 \%$ of all MS patients. The patients with RRMS suffer from relapses and remissions of their neurological symptoms.

2. Secondary progressive MS (SPMS): This follows the development of RRMS and causes further worsening of the disease.

3. Primary progressive MS (PPMS): This affects $8-10 \%$ of patients and is characterized by the gradual further worsening of the disease. 
4. Progressive-relapsing MS (PRMS): This is the least often occurring class, affecting less than $5 \%$ of patients and progressing from onset [8-10].

MS takes place in brain and spinal cord regions containing myelin. As shown in Figure 1, MS lesions involve demyelination and inflammation of B-cells, T-cells, macrophages and activated microglia. Then follows tissue damage, which includes loss of neurons and oligodendrocytes, astrogliosis and remyelination [11,12].

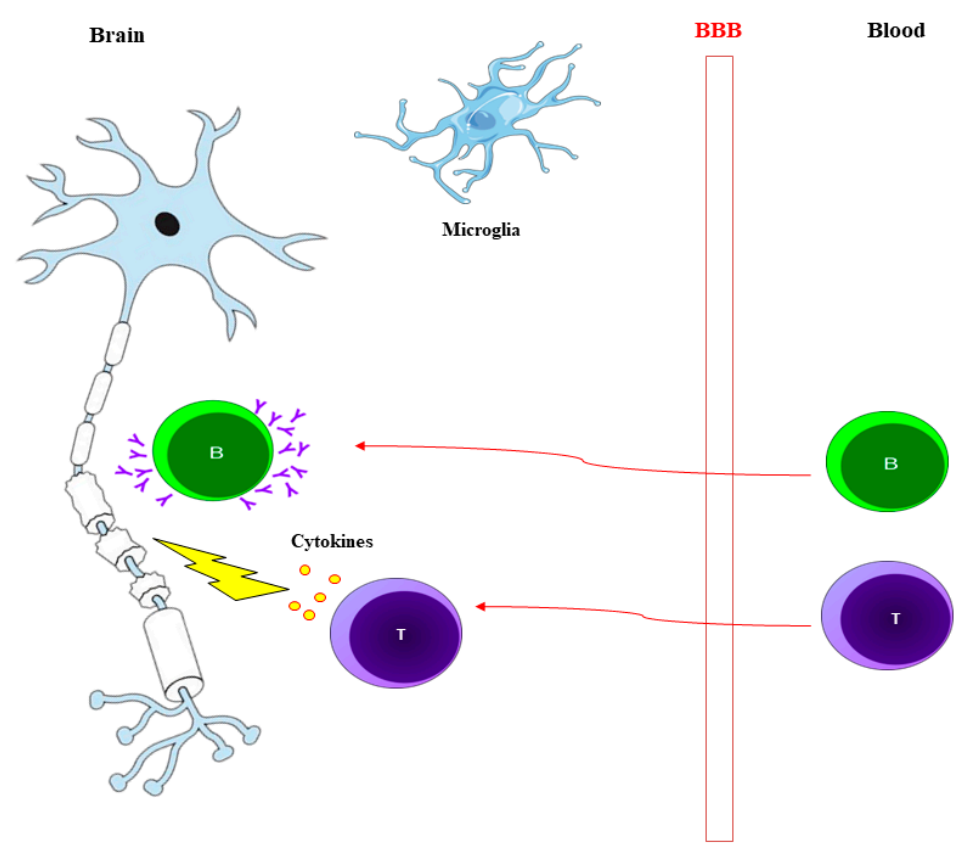

Figure 1. T-cells enter the blood brain barrier (BBB) and release cytokines which degrade the myelin. The cytokines can also recruit some other cells as B-cells. These cells enter the BBB and produce antibodies which target the myelin for further degradation. Activated microglia are also involved in myelin degradation.

The cause of autoimmune disease MS is still mostly unknown. It is hypothesized that environment induces MS in individuals prone to the disease. The molecular mimicry theory has been used to explain the pathogenesis of MS. The gathered evidence proposes that viral peptidic epitopes bearing sequence homology to protein regions of normal human tissue are responsible for the initiation of the disease. The immune response of T-cells targets mainly the viral epitopes. However, cross-reaction with the normal human tissue leads to the autoimmune disease $[13,14]$.

The myelin basic protein (MBP), the proteolipid protein (PLP), the myelinoligodendrocyte glycoprotein (MOG), and the myelin associated oligodendrocytic basic protein (MOBP), have been associated as T-cell epitopes in MS. These peptides have been utilized to trigger experimental autoimmune encephalomyelitis (EAE). EAE is the most frequently and broadly used animal model that simulates MS [15-21].

Although advances in MS treatment have proceeded impressively, the currently available medications are not fully in line to respond to the future and emerging needs raised by the complicated nature of MS [22].

One of the major approaches for the treatment of MS is the peptidic or peptidomimetic therapeutic approach [23,24]. There are different steps involved in the development of peptidomimetic drugs in a rational design strategy. In the first step the minimal peptide amino acid sequence that exerts the activity (epitope) and serves as a lead compound is identified. In the second step the information derived from nuclear magnetic resonance (NMR) spectroscopy, and/or molecular modeling and/or x-ray crystallography is utilized in order to define a putative bioactive conformation of the minimal 
peptide sequence [25]. In the third step the resultant 3D architecture is used for the development of non-peptide mimetics that are prone to metabolic clearance.

Activated encephalitogenic T-cells, triggered by the formation of a trimolecular complex between the T-cell receptor (TCR), the peptide (antigen) — with identical residue sequence to a fragment of a protein of the myelin sheath-and the major histocompatibility complex (MHC) or human leukocyte antigen (HLA), initiate the onset of MS. The potential of the peptide-HLA complex to activate T-cells parallels the strength of its binding affinity with TCR [26-28]. It follows the stimulation, or not, of T-cells that cause MS [29-33].

The dimer HLA class II receptors contain two polypeptide chains named as $\alpha$ and $\beta$ [34,35]. Their joined polypeptide chains form a single receptor suitable to form a complex with the antigen binders. This complex is recognized by the T-cell receptors on the cell surface. The formed trimolecular complex leads to the activation of T-cells through a series of biochemical alterations and the triggering of the immune response to the antigen [36].

This review summarizes the conformational analysis of peptides involved in multiple sclerosis. In addition the impact of these conformational changes on rational drug design is described.

\section{Results and Discussion}

Mouzaki et al. [37] pointed out that peptides constitute a class of administered molecules as immunomodulatory drugs due to their rapid and cost-effective synthesis. The peptides that can cause EAE in animals are called agonists and those that can compete the action of the agonists and treat EAE are called antagonists.

In the discussed studies peptides are used that either map to wild-type MBP, PLP [38] or MOG epitopes or are mutants (altered peptide ligands, APLs), which are linear or cyclized variants that are more resistant to in vivo enzymatic degradation [39]. APLs differ from their parent encephalitogenic peptides by single amino acid substitutions and can inhibit autoimmune mediated disease through several mechanisms.

For many years we have made an effort to explore the conformational properties that govern various epitopes related to EAE with their agonist and antagonists both in solution and in trimolecular complexes (drug:TCR:HLA). In this review we will outline the most significant results obtained from these studies.

The first step in these studies is to extract favored averaged conformations of the epitopes in solution using NMR spectroscopy. These conformations after energy minimization serve as initial conformations for applying molecular dynamics (MD) simulations in the generation of the trimolecular complex. The results will lead to the synthesis of antagonist peptides which could potentially provide useful mechanistic information to combat MS (Figure 2).

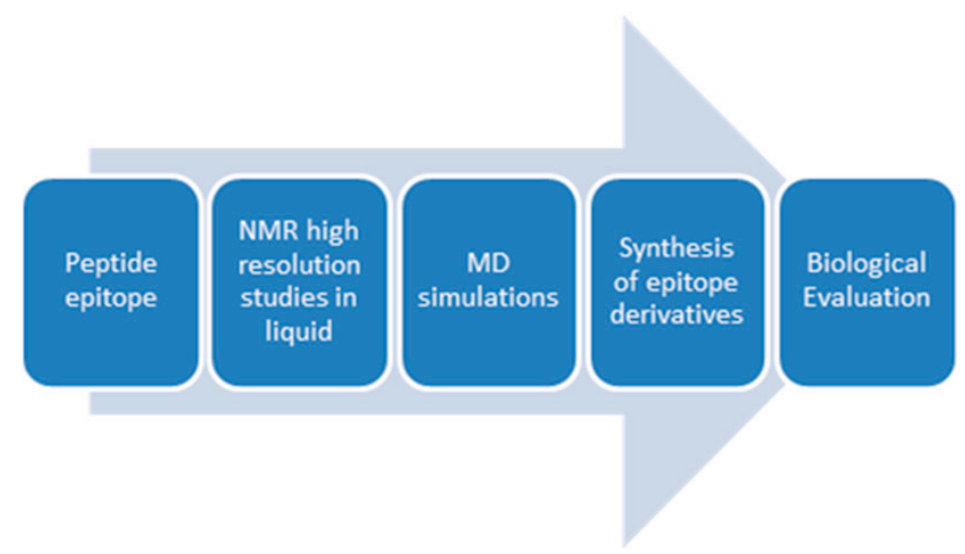

Figure 2. Steps of a rational design process aiming to aid the development of peptide mimics against multiple sclerosis (MS). 
The conformational analysis of $\mathrm{hMOG}_{35-55}$ epitope (Met ${ }_{35}$-Glu-Val-Gly-Trp-Tyr-Arg-Pro ${ }^{42}$-ProPhe-Ser-Arg-Val-Val-His-Leu-Tyr-Arg-Asn-Gly-Lys $\left.{ }_{55}\right)$ and its mutants (hMOG ${ }_{35-55}\left(\mathrm{Ala}^{41}\right)$ and $\mathrm{hMOG}_{35-55}\left(\mathrm{Ala}^{41,46}\right)$ ) alone and in the trimolecular complex containing HLA and TCR have been studied using MD simulations [36]. The results showed that the $\mathrm{hMOG}_{35-55}$ epitope in the MD trajectory does not retain the linear conformation. Its dominant conformation shows two bends in the polypeptide backbone between residues $\operatorname{Tr}^{39}, \operatorname{Tyr}^{40}$ and $\operatorname{Arg}^{41}$ and $\mathrm{Val}^{48}$ and $\mathrm{Arg}^{52}$.

This conformation is similar to that published for the rat/mouse $\mathrm{MOG}_{35-55}$ peptide by Ntountaniotis et al. [40] in DMSO and $\mathrm{D}_{2} \mathrm{O}$ solvents (Figure 3).

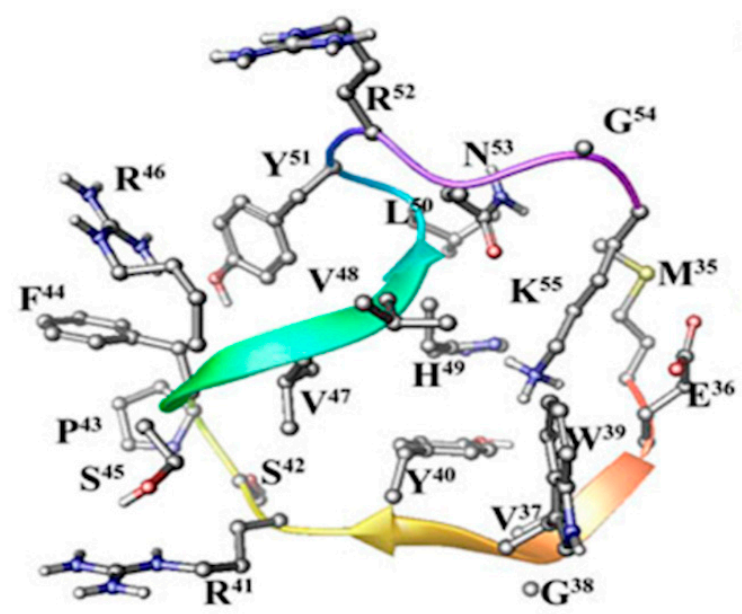

Figure 3. Low energy conformer of $\mathrm{hMOG}_{35-55}$ (myelinoligodendrocyte glycoprotein) derived from in silico molecular synamics (MD) calculations restricted with nuclear Overhauser effect (NOE)-constraints.

During the formation of the trimolecular complex the amino acids $\mathrm{Arg}^{41}$ and $\mathrm{Arg}^{46}$ of $\mathrm{hMOG}_{35-55}$ anchor at TCR and $\mathrm{Tyr}^{40}$ interacts with HLA. The amino acids $\mathrm{Arg}^{41}$ and $\mathrm{Arg}^{46}$ form an extensive hydrogen bonding (HB) network with both receptors. Substitution of $\mathrm{Arg}^{41}$ or $^{\mathrm{Arg}}{ }^{41}$ and $\mathrm{Arg}^{46}$ with Ala leads to the two mutants $\mathrm{hMOG}_{35-55}\left(\mathrm{Ala}^{41}\right)$ and $\mathrm{hMOG}_{35-55}\left(\mathrm{Ala}^{41}, \mathrm{Ala}^{46}\right)$. These mutations lead to the elimination of key interactions with TCR but leave intact the binding affinity towards the HLA receptor. These two mutants function as EAE inhibitors. This finding is significant as it provides basic mechanistic aspects of the action of agonist versus antagonist peptides (Figure 4).

The conformational analysis of $\mathrm{MBP}_{77-89}$ and the antagonist altered ligands $\left(\mathrm{Arg}^{91}, \mathrm{Ala}^{96}\right) \mathrm{MBP}_{87-99}$ and $\left(\mathrm{Ala}^{91,96}\right) \mathrm{MBP}_{87-99}$ have been studied. All the three molecules showed an extended conformation in DMSO environment with no long-range nuclear Overhauser effects (NOEs) [41] in disagreement with the observations recorded in other chemical environments [29].

Interestingly, X-ray results existed for a peptide analogue of $\mathrm{MBP}_{87-99}$ that formed a trimolecular complex with a human TCR and HLA-DR2b [42]. A bioactive conformation of APL that resembled that of the crystallized peptide was derived from the molecular dynamics trajectories (Root-Mean Square Deviation (RMSD) value of $0.95 \AA$ ). The two peptides were oriented similarly to the two TCR anchor residues, $\mathrm{His}^{88}$ and $\mathrm{Phe}^{89}$, and the HLA anchor residue Phe ${ }^{90}$.

These two amino acids orient variably in the trimolecular complex for $\left(\mathrm{Arg}^{91}, \mathrm{Ala}^{96}\right) \mathrm{MBP}_{87-99}$ and $\left(\mathrm{Ala}^{91,96}\right) \mathrm{MBP}_{87-99}$, and remain buried in HLA grooves and cannot interact with the TCR. This finding may explain the antagonism of the two altered ligands (Figure 5). 


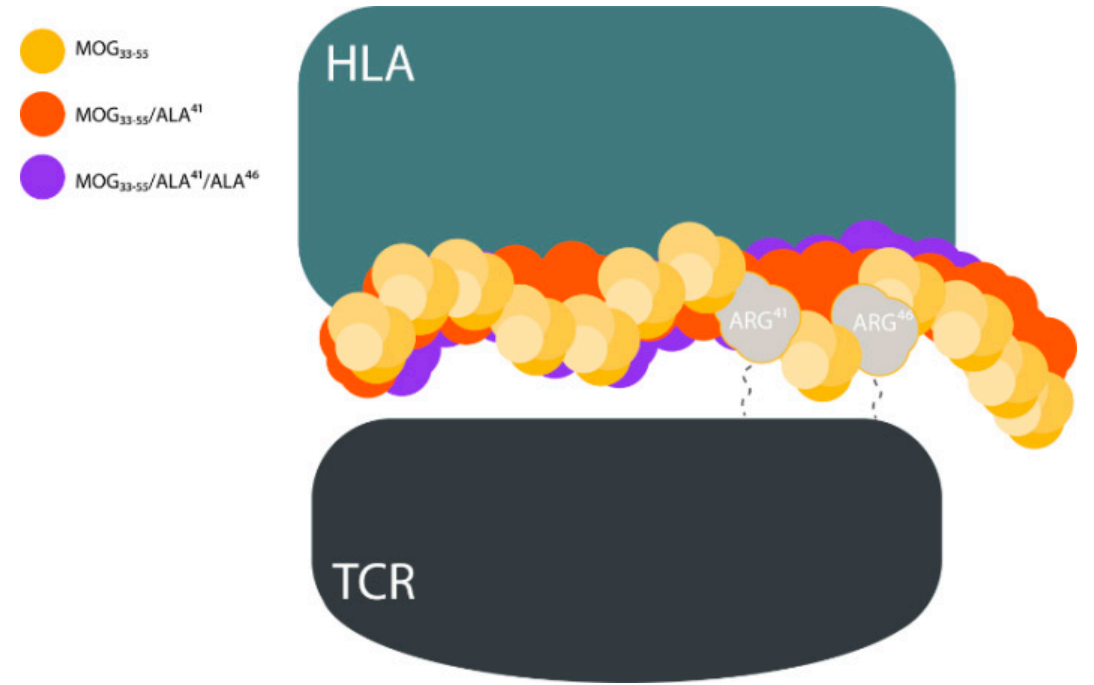

Figure 4. The replacement of $\mathrm{Arg}^{41}$ or $\mathrm{Arg}^{41}$ and $\mathrm{Arg}^{46}$ of $\mathrm{hMOG}_{35-55}$ with Ala interrupts the hydrogen bonding (HB) with the amino acids $\mathrm{Asp}^{98}$, Ser ${ }^{101}$, and $\mathrm{Asn}^{104}$ of T-cell receptors (TCR). This may be due to the decrease of polarity of Ala vs. Arg (disruption of the interaction network) and may lead to a reduced bending of Ala in the low energy conformation of hMOG $35-55$. HLA-Human Leukocyte Antigen.
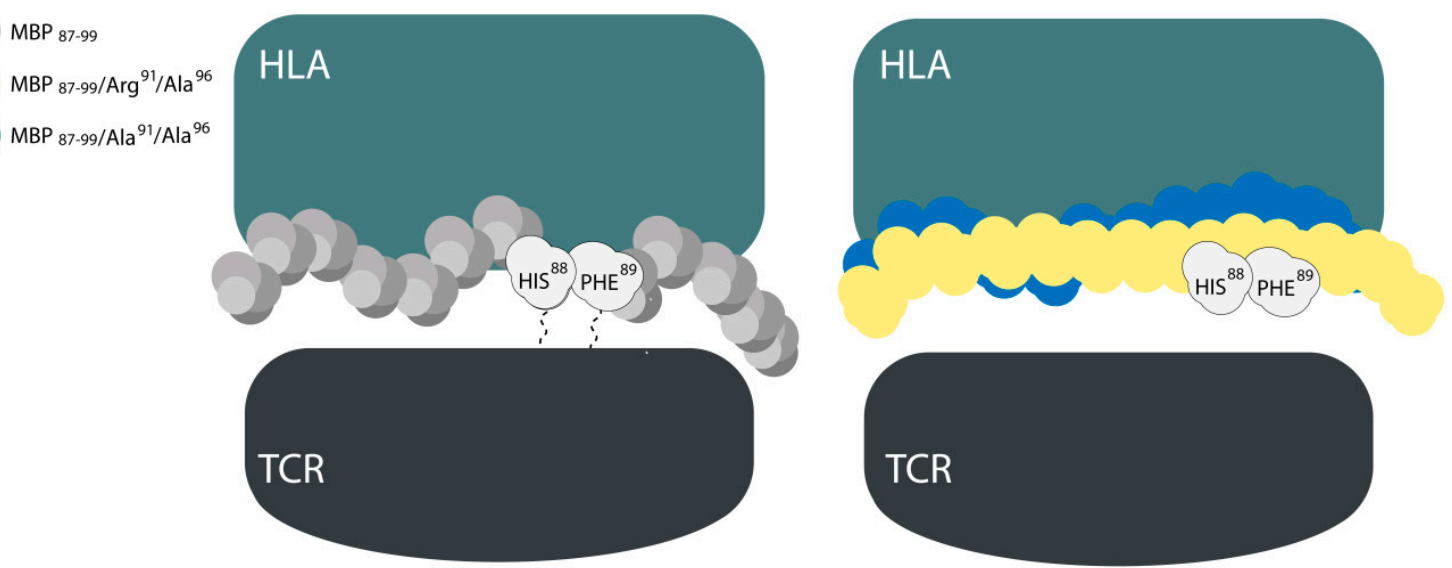

Figure 5. (left) $\mathrm{His}^{88}$ and $\mathrm{Phe}^{89}$ of $\mathrm{hMBP}_{87-99}$ (myelin basic protein) interact with the TCR receptor. (right) In the two antagonists $\left(\mathrm{Arg}^{91}, \mathrm{Ala}^{96}\right) \mathrm{MBP}_{87-99}$ and $\left(\mathrm{Ala}^{91,96}\right) \mathrm{MBP}_{87-99}$ this interaction is lost as the two amino acids are buried in HLA grooves.

The cyclo (91-99)(Ala $\left.{ }^{96}\right) \mathrm{MBP}_{87-99,}$ cyclo(87-99)(Ala $\left.{ }^{91,96}\right) \mathrm{MBP}_{87-99}$ and cyclo(87-99)(Arg ${ }^{91}$, $\left.\mathrm{Ala}^{96}\right) \mathrm{MBP}_{87-99}$ (Figure 6), except the wild-type linear $\mathrm{MBP}_{87-99}$, were found to strongly inhibit $\mathrm{MBP}_{72-85}$ - induced EAE in Lewis rats. Cyclo(87-99)( $\mathrm{Arg}^{91}$, Ala $\left.{ }^{96}\right) \mathrm{MBP}_{87-99}$ provided long protection for the EAE induction $[39,43,44]$.

Conformational analysis was achieved for the three cyclo(87-99) MBP 87-99, cyclo(87-99) (Ala $\left.{ }^{91,96}\right) \mathrm{MBP}_{87-99}$, and cyclo(87-99) (Arg $\left.{ }^{91}, \mathrm{Ala}^{96}\right) \mathrm{MBP}_{87-99}$ analogs using 2D NMR spectroscopy and computational analysis. The conformational analysis of the three synthetic analogues showed that their bioactivity, or its absence, may be attributed to the distinct local conformation, overall topology and exposed area after binding with MHC II. An overall larger solvent accessible area may occlude the approach and binding of the TCR on the APL-MHC complex. In contrast, more compact structures do not block weak interactions as TCR approaches and can induce EAE antagonism. These results led to the generation of the pharmacophore model described in Figure 7 [45]. 
cyclo (87-99) MPB $87-99$

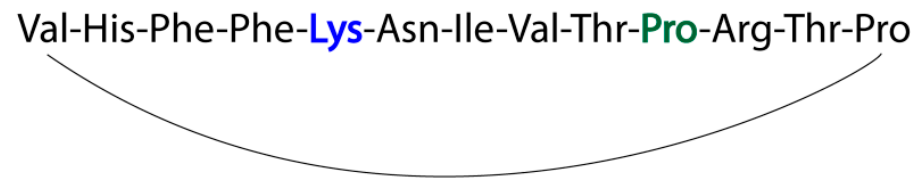

cyclo (87-99) $\left[\mathrm{Ala}^{91 / 96}\right]$ MPB $87-99$
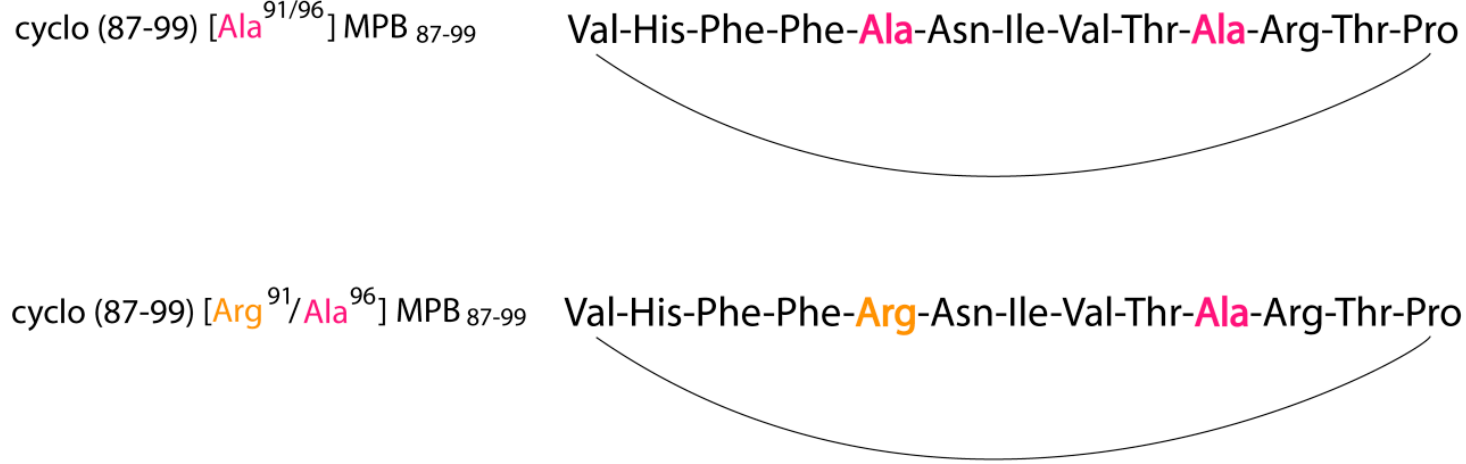

Figure 6. Structures of cyclo(91-99)( $\left.\mathrm{Ala}^{96}\right) \mathrm{MBP}_{87-99}, \mathrm{cyclo}(87-99)\left(\mathrm{Ala}^{91},{ }^{96}\right) \mathrm{MBP}_{87-99}$ and cyclo(87-99)( $\mathrm{Arg}^{91}$, $\left.\mathrm{Ala}^{96}\right) \mathrm{MBP}_{87-99}$.

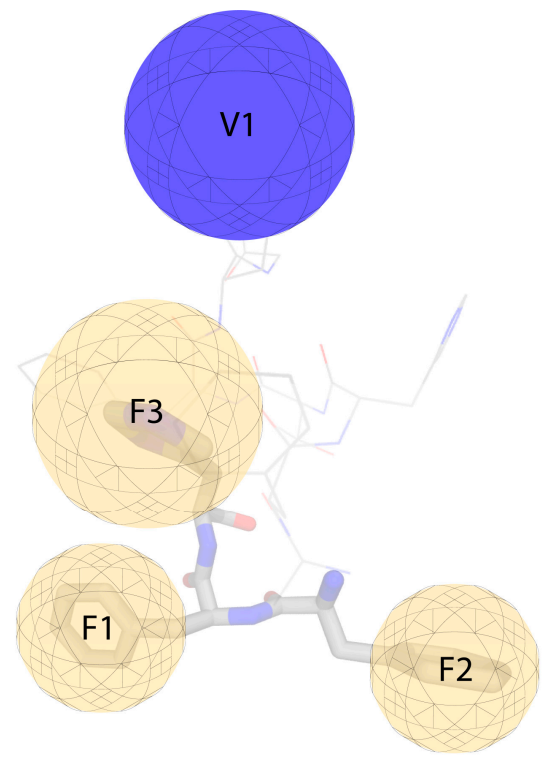

Figure 7. Pharmacophore model depicted using the conformational properties obtained from the conformational analysis for the cyclic altered peptide ligands (APLs). Exclusion volume V1 is presented with a blue sphere, feature F1 $\left(\mathrm{Phe}^{90}\right)$, F2 $\left(\mathrm{Phe}^{89}\right), \mathrm{F} 3\left(\mathrm{Phe}^{88}\right)$ with a yellow sphere.

Two citrullinated peptides, the linear $\left(\mathrm{Cit}^{91}, \mathrm{Ala}^{96}, \mathrm{Cit}^{97}\right) \mathrm{MBP}_{87-99}$ and cyclo(87-99)(Cit ${ }^{91}, \mathrm{Ala}^{96}$, $\left.\mathrm{Cit}^{97}\right) \mathrm{MBP}_{87-99}$ have been synthesized by citrullinating the Arg residues 91 and 97 in the antagonists, linear (Arg91, Ala96)MBP $87-99$ and cyclo(87-99)(Arg ${ }^{91}$, Ala $\left.{ }^{96}\right) \mathrm{MBP}_{87-99}$ peptides. In contrast to the antagonists, these citrullinated molecules induced EAE. Molecular modeling results pointed out that both $\mathrm{Cit}^{91}$ and $\mathrm{Cit}^{97}$ residues are oriented toward the TCR and possibly are interacting with the complementarity-determining region (CDR3) loops of the TCR, thus triggering an altered cytokine response [46].

Another epitope which is shown to induce EAE in guinea pigs is the linear peptide $\mathrm{MBP}_{74-85}\left(\mathrm{Gln}^{1}-\mathrm{Lys}^{2}-\mathrm{Ser}^{3}-\mathrm{Gln}^{4}-\mathrm{Arg}^{5}-\mathrm{Ser}^{6}-\mathrm{Gln}^{7}-\mathrm{Asp}^{8}-\mathrm{Glu}^{9}-\mathrm{Asn}^{10}-\mathrm{Pro}^{11}-\mathrm{Val}^{12}-\mathrm{NH}_{2}\right)$. A Rotating frame Overhauser Effect Spectroscopy (ROESY) connectivity was observed for the molecule in DMSO between $\alpha \mathrm{Val}^{12}-\alpha \mathrm{Gln}^{1}$, suggesting a cyclic conformation. This intriguing result prompted the synthesis of 
the cyclic analogue by tethering the $\varepsilon \mathrm{NH}_{2}$ of Lys and $\gamma \mathrm{COOH}$ of Glu at positions 2 and 9, respectively. Cyclic peptides are well known to be more stable and less susceptible to enzymatic degradation than linear peptides. Moreover, cyclic peptides are an important intermediate step in the rational design and development of non-peptide mimetics [47].

This cyclic analogue illustrated comparable bioactivity with the linear one, confirming that the possible bioactive conformation of $\mathrm{MBP}_{74-85}$ resembles that of the cyclic variant or the cyclic variant resembles more, from the available ensemble, the structure of the linear peptide that is of biological significance. The structures of the linear and cyclic analogues are shown in Figure 8 . The same relationship was observed with the linear $\mathrm{Ala}^{81} \mathrm{MBP}_{74-85}$ and its cyclic analogue [25].

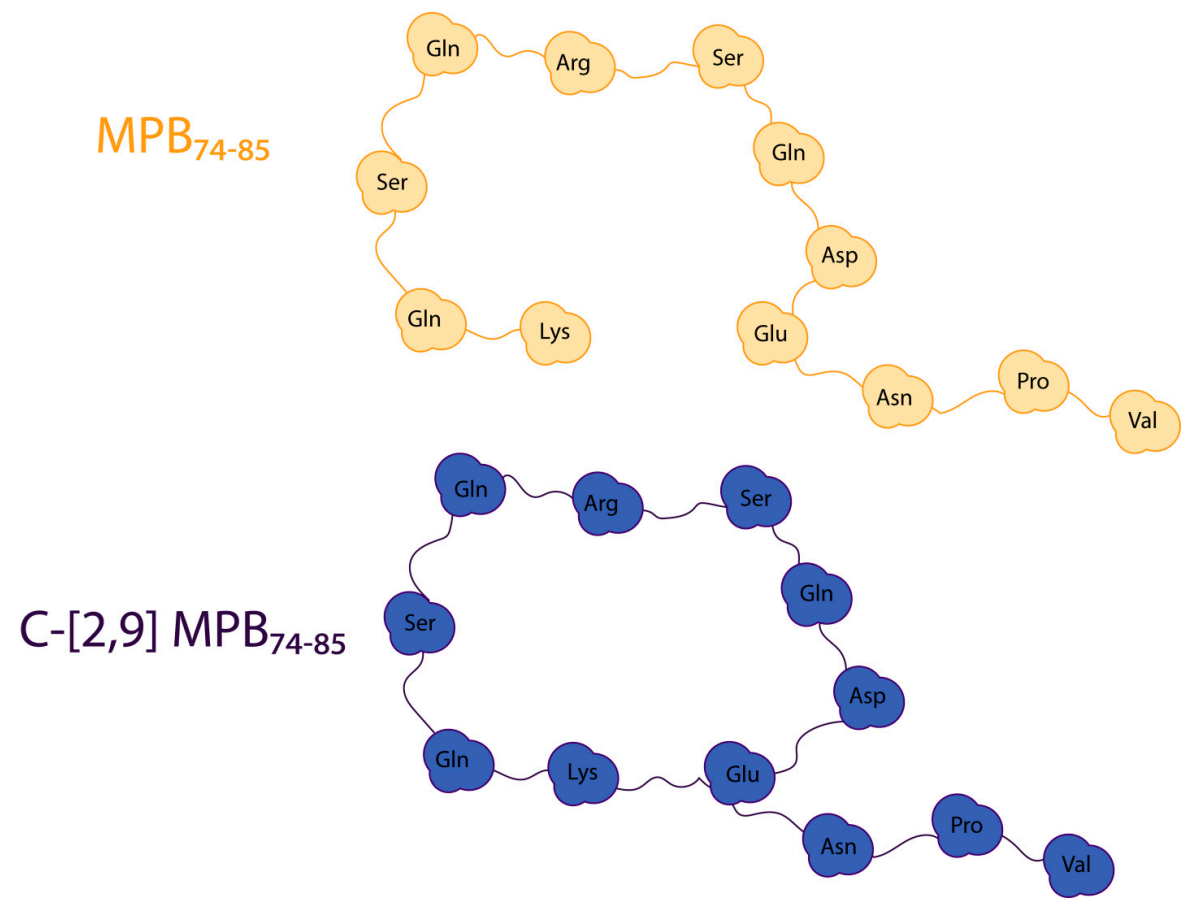

Figure 8. 2D and 3D models of linear $\mathrm{MBP}_{74-85}$ (top) and its cyclic analogue (bottom).

Tzakos et al. [48] applied NMR and molecular dynamic simulations to study the conformational

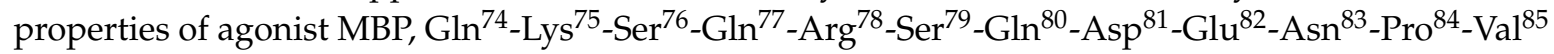
$\left(\mathrm{MBP}_{(74-85)}\right)$, and its antagonist analogue $\mathrm{Ala}^{81} \mathrm{MBP}_{(74-85)}$. The agonist $\mathrm{MBP}_{(74-85)}$ adopted a compact conformation attributed to electrostatic interactions of $\mathrm{Arg}^{78}$ with the side chains of Asp ${ }^{81}$ and Glu $^{82}$. $\mathrm{Arg}^{78}$ adopted a well-defined conformation, which did not depend on the solvent. Such electrostatic interactions were not observed in the antagonist $\mathrm{Ala}^{81} \mathrm{MBP}_{(74-85)}$, and a high flexibility of the side chain of $\mathrm{Arg}^{78}$ was observed. The positively charged residue $\mathrm{Arg}^{78}$ is suggested to stabilize the local microdomains (epitopes) of the integral protein. Flexible docking calculations point out that $\mathrm{Gln}^{74}$, Ser ${ }^{76}$ and $\mathrm{Ser}^{79}$ are MHC II anchor residues. $\mathrm{Lys}^{75}$, $\mathrm{Arg}^{78}$ and Asp ${ }^{81}$ are the mainly solvent-exposed residues and this may signify their participation in the formation of the trimolecular T-cell receptor- $\mathrm{MBP}_{(74-85)}-\mathrm{MHC}$ II complex.

In another study the conformational analysis of the immunodominant epitope of acetylated myelin basic protein residues 1-11 (Ac-MBP1-11) and its ALPs, mutated at position 4 to an alanine (Ac-MBP1-11(4A)) or a tyrosine residue (Ac-MBP1-11(4Y)), was achieved. The amino acids constituting the $\mathrm{MBP}^{1-11}$ are Ala-Ser-Gln-Lys-Arg-Pro-Ser-Gln-Arg-His-Gly (Ac-MBP1-11). The Ac-MBP1-11(4A) analogue inhibited EAE symptoms induced by encephalitogenic Ac-MBP1-11 epitope when co-injected in $(\mathrm{PL} / \mathrm{J} \times \mathrm{SJL}) \mathrm{F} 1$ mice. These results are interpreted to suggest that Ac-MBP1-11(4A) induced immunomodulation that inhibits EAE in vivo [49]. Studies indicated that the residue at position 4 in MBP1-11 peptide plays a major role in binding of the peptide to MHC class II, I-Au [50,51]. 
The mutated analogue Ac-MBP1-11(4A) binds to I-Au with a minimum of 50-fold higher affinity in comparison to the native Ac-MBP1-11 [52]. In addition, the mutation at position 4 of Lys to Tyr (Ac-MBP1-11(4Y)) increases the stability of the I-Au-peptide complex by enhancing 1500-fold the affinity, which triggers Ac-MBP1-11 T-cells more effectively in relation to Ac-MBP1-11(4A) [53].

The conformational analysis of the three analogues showed that they adopt an extended conformation in deuterated DMSO solvent due to the absence of long-distance NOEs. Furthermore, they adopt a similar conformation when bound to the active site of the MHC II. Gln ${ }^{3}$ residue is a TCR contact site and has a different orientation in the mutated analogues. Specifically, its side chain is not solvent exposed, and it is not available for interaction with the TCR. The main MHC contact residues $\left(\mathrm{Ser}^{2}, \mathrm{Pro}^{6}\right.$ and $\left.\mathrm{Ser}^{7}\right)$ stand in the same position for all peptides [54].

The conformational properties of $\mathrm{MBP}_{83-99}$ have been studied using NMR spectroscopy in DMSO to simulate the biological environment. The results showed that the peptide exists in a rather extended conformation and forms a helix between $\mathrm{Val}^{87}$ and $\mathrm{Phe}^{90}$ [55].

Two analogues of the $\mathrm{MBP}_{83-99}$ epitope substituted at Lys ${ }^{91}$ (primary TCR contact) with Phe $\left(\mathrm{MBP}_{83-99}\left(\mathrm{Phe}^{91}\right)\right)$ or Tyr $\left(\mathrm{MBP}_{83-99}\left(\mathrm{Tyr}^{91}\right)\right)$ were synthesized (Figure 9).

\section{A) $\mathrm{MPB} 83-99$}

A)

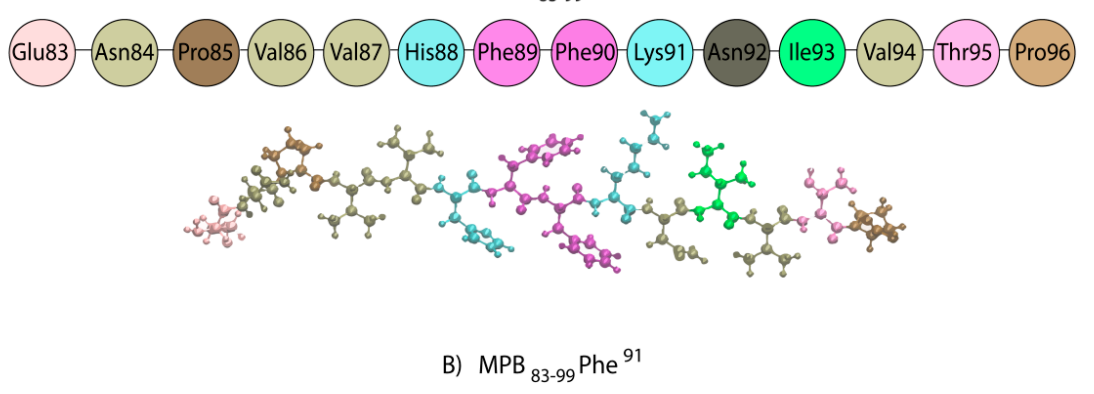

B)
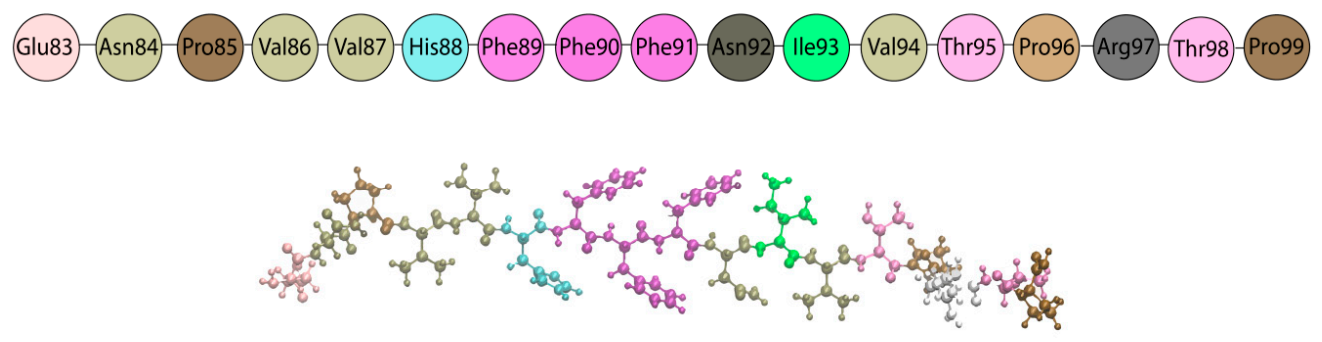

C) $\mathrm{MPB}_{83-99} \mathrm{Tyr}^{91}$

C)

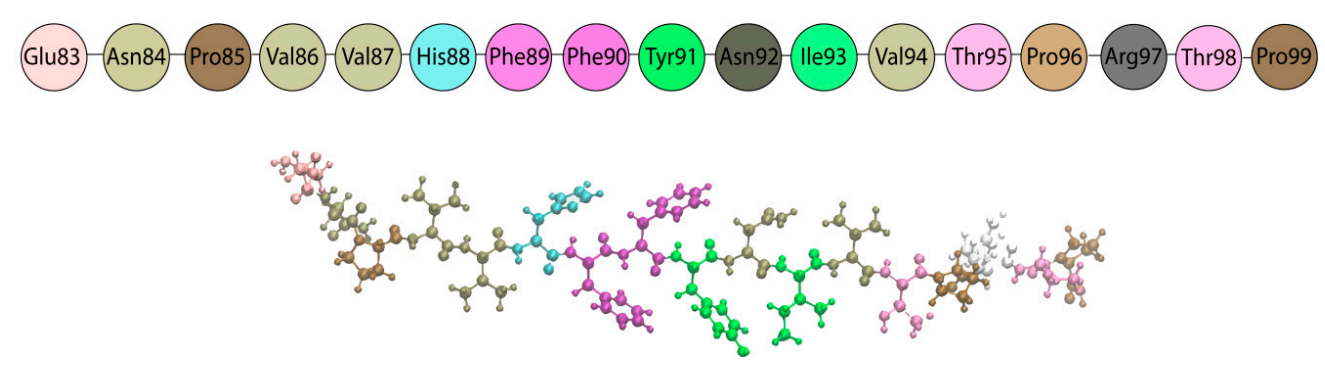

Figure 9. Sequences and 3D low energy structures of $(\mathbf{A}) \mathrm{MBP}_{83-96}$ (numbering is according to the human $\mathrm{MBP}_{83-99}$ epitope) and the two synthetic analogs (B) MBP $83-99\left(\mathrm{Phe}^{91}\right)$ and (C) $\mathrm{MBP}_{83-99}\left(\mathrm{Tyr}^{91}\right)$.

The two analogues showed distinct antagonistic activity versus the agonistic activity of the $\mathrm{MBP}_{83-99}$ epitope. The conformational analysis of the two APLs was performed using NMR spectroscopy and MD. Both synthetic analogues show an extended conformation in agreement with the structural features of the peptides that interact with the HLA-DR2 and TCR receptors. MD simulations of the two analogues in complex with HLA-DR2 (DRA, DRB1*1501) and TCR revealed 
their modes of interactions. $\mathrm{MBP}_{83-99}\left(\mathrm{Phe}^{91}\right)$ analogue adopts more interactions during the formation of the trimolecular complex relatively to $\mathrm{MBP}_{83-99}\left(\mathrm{Tyr}^{91}\right)$, as their trajectory profiles confirmed. This may explain the improved biological profile of the latter. The two analogues differ in the way of binding relatively to the wild epitope $\mathrm{MBP}_{83-96}$. This is attributed to the fact that mutation of Lys ${ }^{91}$ by either Tyr or Phe alters their stereoelectronic properties.

This alteration of the stereoelectronic properties affects the binding mode of the regional amino acids and explains their antagonistic or agonistic activity. Such binding mode differences have been observed and outlined above with the $\mathrm{MBP}_{87-99}$ epitope $[45,56-60]$.

It is important to note that although the two peptides mentioned above differ only in a small segment, they possess distinct biological profiles. The tyrosine ${ }^{91}$ in $\mathrm{MBP}_{83-99}\left(\mathrm{Tyr}^{91}\right.$ ) possesses a phenolic hydroxyl group that induces differential biological activity. This is in agreement with a plethora of literature data pointing out the key role of the phenolic group in drug bioactivity [61-72] (Figure 10).

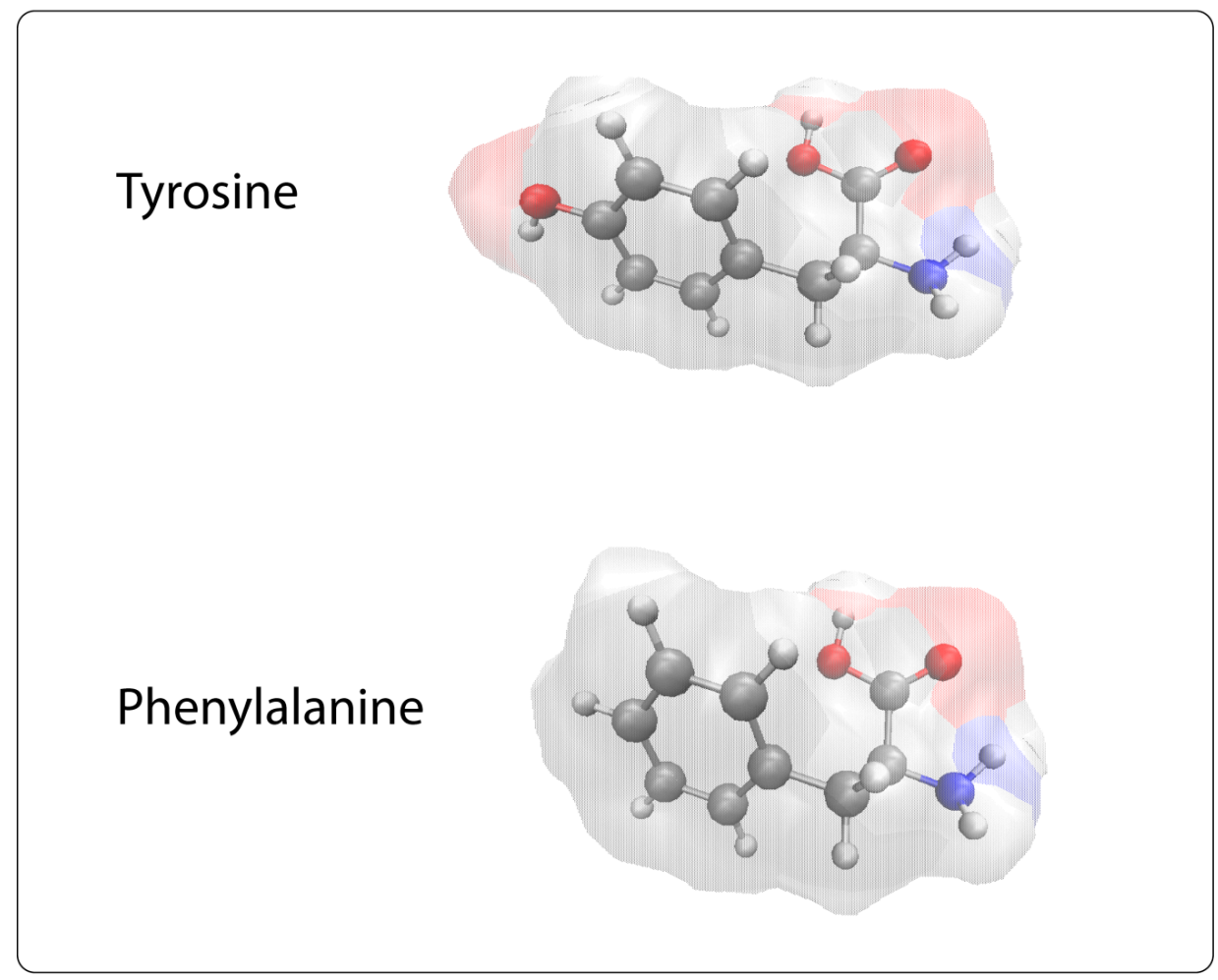

Figure 10. The absence of the phenolic hydroxyl group in Phe is responsible for the different biological properties between the two synthetic analogues $\mathrm{MBP}_{83-99}\left(\mathrm{Tyr}^{91}\right)$ and $\mathrm{MBP}_{83-99}\left(\mathrm{Phe}^{91}\right)$.

The superimposition of the two peptides at the binding site of the trimolecular complex shows that $\mathrm{Phe}^{91}$ and $\mathrm{Tyr}^{91}$ occupy almost identical areas. However, they induce different conformations to other vicinal amino acids $\mathrm{Asn}^{92}$ and $\mathrm{Ile}^{93}$, as the phenolic hydroxyl group lies in a relatively hydrophobic environment. Their apparently small structural difference induces a sequence of distinct interactions that determine their fingerprint of biological action. $\mathrm{MBP}_{(85-99)}$ is an immuno-dominant epitope of MBP which binds to the MHC haplotype HLA-DR2 and is associated with the pathogenesis of MS. The synthetic 15-mer peptide J5n (Figure 11), was designed and was found to antagonize $\mathrm{MBP}_{(85-99)}$ through the binding of $\mathrm{MBP}_{(85-99)}$ to soluble HLA-DR2b [73]. The therapeutic efficacy of J5 is limited, probably due to its low biological half-life or bioavailability. The structural features of J5 in relation to its parent (i.e., $\mathrm{MBP}_{(85-99)}$ ) are shown in Figure 11. Phe at position $\mathrm{P} 4$ has been replaced with Tyr, Val at position P1 has been retained and His, Phe, and Lys at P2, P3 and P5 have been replaced with Glu, Ala and Lys, respectively. 
(a)<smiles>[R][C@H](N)C(=O)O</smiles>

(b)<smiles>[R][C@H](N)CC(=O)O</smiles>

(c)

$\begin{array}{llllll}\text { P1 P2 } & \text { P3 } & \text { P4 } & \text { P5 }\end{array}$

\begin{tabular}{ll}
$\mathrm{MBP}_{85-99}$ & Glu-Asn-Pro-Val-Val-His-Phe-Phe-Lys-Asn-Ile-Val-Pro-Thr-Arg \\
\hline $\mathrm{J}_{5}$ & Glu-Lys-Pro-Lys-Val-Glu-Ala-Tyr-Lys-Ala-Ala-Ala-Ala-Pro-Ala \\
\hline $\mathrm{S}_{18}$ & Glu $_{\beta}{ }^{3}$-Lys ${ }_{\beta}{ }^{3}$-Pro-Lys-Val-Glu-Ala-Tyr-Lys ${ }_{\beta}{ }^{3}-\mathrm{Ala}_{\beta}{ }^{3}-\mathrm{Ala}_{\beta}{ }^{3}-\mathrm{Ala}_{\beta}{ }^{3}-\mathrm{Ala}_{\beta}{ }^{3}$
\end{tabular}

Figure 11. (a) $\alpha$-amino acid, (b) Homo- $\beta$-amino acid, (c) $\mathrm{MBP}_{85-99}$, J5 and $\mathrm{S}_{18}$ analogue.

In another study J5 was derivatized into analogs possessing superior biological half-lives and antagonistic activities. This is achieved by substitution of some of its residues with homo- $\beta$-amino acids. S18 (Figure 11), the most active analog, ameliorated symptoms of EAE at least twice more effectively than glatiramer acetate or J5. S18 showed high resistance to proteolysis, which contributed to a delayed clinical onset of disease and prolonged therapeutic benefits [74].

The conformational analysis studies of $\mathrm{MBP}_{83-96}$ epitope led the group of Professor T. Tselios to search for the mining and synthesis of non-peptide mimetic molecules. In particular, they sought molecules that inhibit the trimolecular complex formation and consequently the proliferation of activated T-cells. They generated a structure-based pharmacophore and used ZINC as a chemical database to extract candidates (Figure 12). Semi-empirical and density functional theory (DFT) methods were performed to predict the binding energy between the proposed non-peptide mimetics and the TCR. From the six synthesized molecules the following 15 and 16 were the most promising as they inhibited the stimulation of T-cells by the immunodominant $\mathrm{MBP}_{83-99}$ from immunized mice [75].
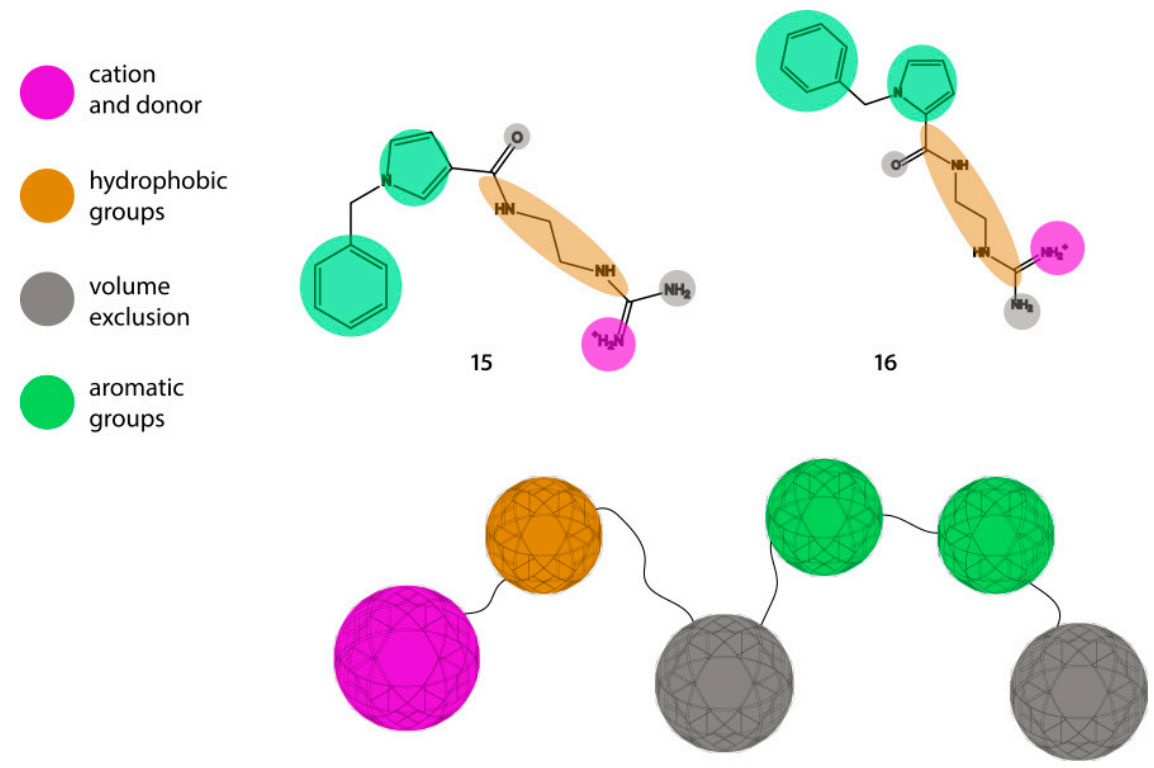

Figure 12. Structure-based pharmacophore derived from ZINC database data. 


\section{Conclusions}

An extensive effort has been made the last years to explore the conformational properties of key peptides involved in MS. The conformational analysis of the different epitopes, consisting of in silico MD and pharmacophore studies, along with NMR spectroscopy, has led to the rational design of some bioactive non-peptide mimetics and provided some mechanistic input of the agonistic and antagonistic action of ALPs. However, there is still a long way towards the generation of more potent compounds. Interestingly, in a study it was illustrated that the extent of MHC or TCR competition does not successfully predict the EAE treatment [76]. Other routes to treat MS had also limited success [21,77].

Such an example is the immunomodulatory co-polymer 1 (Copaxone, glatiramer acetate) drug. This contains synthetic peptides composed of nonspecific sequences of four amino acids: L-alanine, L-lysine, L-glutamic acid and L-tyrosine (Figure 13). As its composition is based on the amino acid structure of MBP it exerts an antagonistic action to the 82-100 epitope of MBP [78].

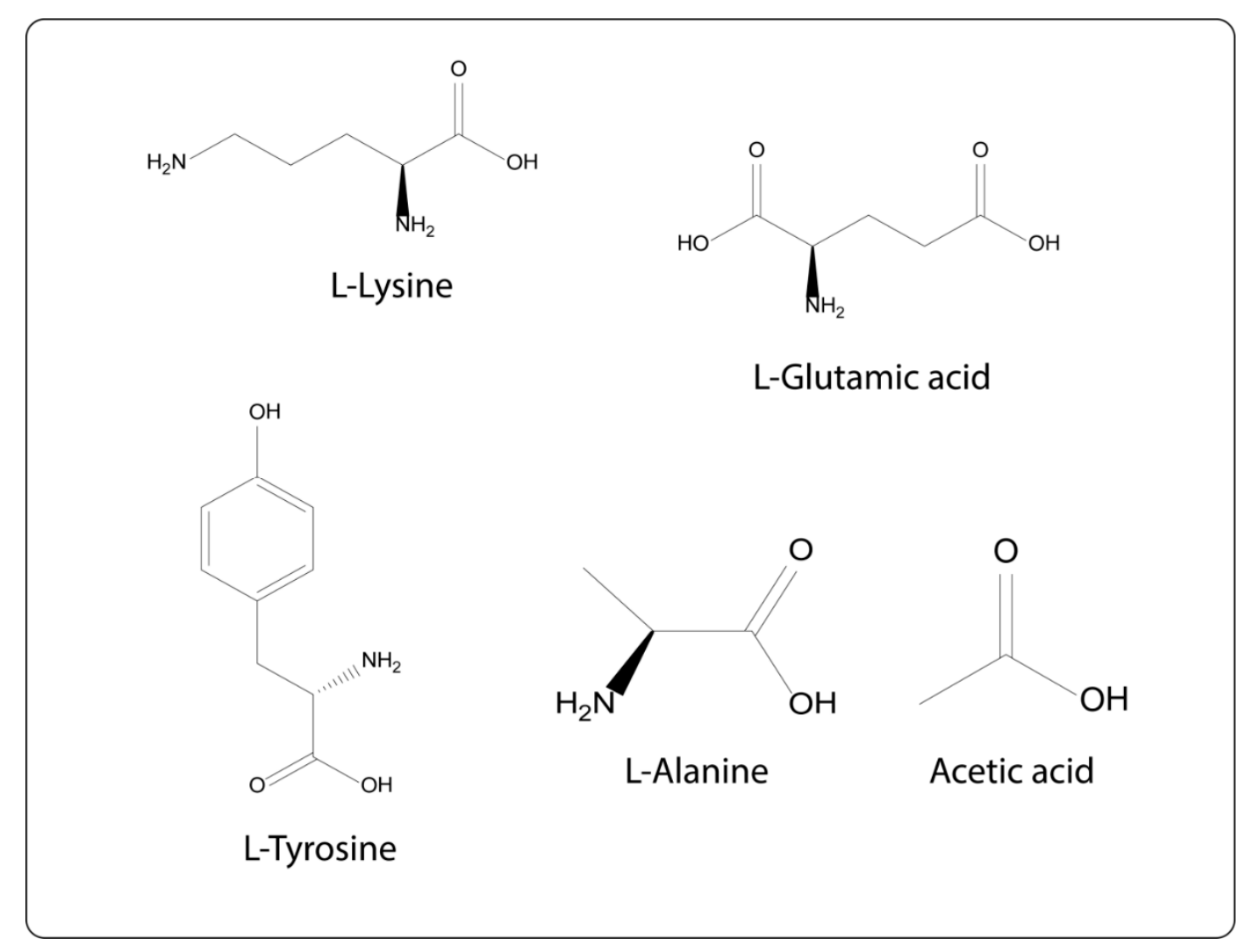

Figure 13. Synthetic peptides of Cop1 structure.

Recently, semi-empirical calculations have been applied to detect peptides associated with MS. It was found that the A_31:01 allele may be associated with the MS disease and the peptide Leu-Ile-Ile-Cys-Tyr-Asn-Trp-Leu-His-Arg may serve as a potential epitope to this allele. This finding must be confirmed by experimental evidence [79].

The multifactorial aspects of MS, especially in its severe state, makes the task of finding a drug against MS tremendously difficult. This must reinforce the efforts in order to advance the progress of understanding and treating the disease.

Author Contributions: Conceptualization, C.K., E.C., S.K., A.G.T.; writing-original draft preparation, T.M.; writing-review and editing, C.K., E.C., S.K., visualization, C.K., E.C., S.K., A.G.T.; supervision, T.M.; project administration, T.M. All authors have read and agreed to the published version of the manuscript.

Funding: This research received no external funding. 
Conflicts of Interest: The authors declare no conflict of interest.

\section{References}

1. Wallin, M.T.; Culpepper, W.J.; Campbell, J.D.; Nelson, L.M.; Langer-Gould, A.; Marrie, R.A.; Cutter, G.R.; Kaye, W.E.; Wagner, L.; Tremlett, H.; et al. The prevalence of MS in the United States. Neurology 2019, 92, 1029-1040. [CrossRef] [PubMed]

2. Howard, J.; Trevick, S.; Younger, D.S. Epidemiology of Multiple Sclerosis. Neurol. Clin. 2016, 34, 919-939. [CrossRef]

3. Dziedzic, A.; Miller, E.; Saluk-Bijak, J.; Bijak, M. The gpr17 receptor-A promising goal for therapy and a potential marker of the neurodegenerative process in multiple sclerosis. Int. J. Mol. Sci. 2020, 21, 1852. [CrossRef] [PubMed]

4. Jennum, P.; Wanscher, B.; Frederiksen, J.; Kjellberg, J. The socioeconomic consequences of multiple sclerosis: A controlled national study. Eur. Neuropsychopharmacol. 2012, 22, 36-43. [CrossRef]

5. Raj, R.; Kaprio, J.; Korja, M.; Mikkonen, E.D.; Jousilahti, P.; Siironen, J. Risk of hospitalization with neurodegenerative disease after moderate-to-severe traumatic brain injury in the working-age population: A retrospective cohort study using the Finnish national health registries. PLoS Med. 2017, 14, e1002316. [CrossRef] [PubMed]

6. Melchor, G.S.; Khan, T.; Reger, J.F.; Huang, J.K. Remyelination Pharmacotherapy Investigations Highlight Diverse Mechanisms Underlying Multiple Sclerosis Progression. ACS Pharmacol. Transl. Sci. 2019, 2, 372-386. [CrossRef] [PubMed]

7. Khan, F.; Amatya, B. Rehabilitation in Multiple Sclerosis: A Systematic Review of Systematic Reviews. Arch. Phys. Med. Rehabil. 2017, 98, 353-367. [CrossRef]

8. Eckstein, C.; Bhatti, M.T. Currently approved and emerging oral therapies in multiple sclerosis: An update for the ophthalmologist. Surv. Ophthalmol. 2016, 61, 318-332. [CrossRef]

9. Lublin, F.D.; Reingold, S.C. Defining the clinical course of multiple sclerosis: Results of an international survey. Neurology 1996, 46, 907-911. [CrossRef]

10. Lublin, F.D.; Baier, M.; Cutter, G. Effect of relapses on development of residual deficit in multiple sclerosis. Neurology 2003, 61, 1528-1532. [CrossRef]

11. Hemmer, B.; Archelos, J.J.; Hartung, H.P. New concepts in the immunopathogenesis of multiple sclerosis. Nat. Rev. Neurosci. 2002, 3, 291-301. [CrossRef] [PubMed]

12. Lassmann, H.; Raine, C.S.; Antel, J.; Prineas, J.W. Immunopathology of multiple sclerosis: Report on an international meeting held at the Institute of Neurology of the University of Vienna. J. Neuroimmunol. 1998, 213-217. [CrossRef]

13. Tzakos, A.; Kursula, P.; Troganis, A.; Theodorou, V.; Tselios, T.; Svarnas, C.; Matsoukas, J.; Apostolopoulos, V.; Gerothanassis, I. Structure and Function of the Myelin Proteins: Current Status and Perspectives in Relation to Multiple Sclerosis. Curr. Med. Chem. 2005, 12, 1569-1587. [CrossRef] [PubMed]

14. Kouskoff, V.; Lacaud, G.; Nemazee, D. T cell-independent rescue of B lymphocytes from peripheral immune tolerance. Science 2000, 287, 2501-2513. [CrossRef]

15. Tuusa, J.; Raasakka, A.; Ruskamo, S.; Kursula, P. Myelin-derived and putative molecular mimic peptides share structural properties in aqueous and membrane-like environments. Mult. Scler. Demyelinating Disord. 2017, 2. [CrossRef]

16. Bielekova, B.; Sung, M.-H.; Kadom, N.; Simon, R.; McFarland, H.; Martin, R. Expansion and Functional Relevance of High-Avidity Myelin-Specific CD4 + T Cells in Multiple Sclerosis. J. Immunol. 2004, 172, 3893-3904. [CrossRef]

17. Greer, J.M.; Csurhes, P.A.; Cameron, K.D.; McCombe, P.A.; Good, M.F.; Pender, M.P. Increased immunoreactivity to two overlapping peptides of myelin proteolipid protein in multiple sclerosis. Brain 1997, 120, 1447-1460. [CrossRef]

18. Mendel, I.; De Rosbo, N.K.; Ben-Nun, A. Delineation of the minimal encephalitogenic epitope within the immunodominant region of myelin oligodendrocyte glycoprotein: Diverse V $\beta$ gene usage by $\mathrm{T}$ cells recognizing the core epitope encephalitogenic for $\mathrm{T}$ cell receptor $\mathrm{V} \beta \mathrm{b}$ and $\mathrm{T}$ cell receptor $\mathrm{V} \beta \mathrm{a} \mathrm{H}-2$. Eur. J. Immunol. 1996, 26, 2470-2479. [CrossRef] 
19. De Rosbo, N.K.; Kaye, J.F.; Eisenstein, M.; Mendel, I.; Hoeftberger, R.; Lassmann, H.; Milo, R.; Ben-Nun, A. The Myelin-Associated Oligodendrocytic Basic Protein Region MOBP15-36 Encompasses the Immunodominant Major Encephalitogenic Epitope(s) for SJL/J Mice and Predicted Epitope(s) for Multiple Sclerosis-Associated HLA-DRB1*1501. J. Immunol. 2004, 173, 1426-1435. [CrossRef]

20. Holz, A.; Bielekova, B.; Martin, R.; Oldstone, M.B.A. Myelin-Associated Oligodendrocytic Basic Protein: Identification of an Encephalitogenic Epitope and Association with Multiple Sclerosis. J. Immunol. 2000, 164, 1103-1109. [CrossRef]

21. Denic, A.; Johnson, A.J.; Bieber, A.J.; Warrington, A.E.; Rodriguez, M.; Pirko, I. The relevance of animal models in multiple sclerosis research. Pathophysiology 2011, 18, 21-29. [CrossRef] [PubMed]

22. Gholamzad, M.; Ebtekar, M.; Ardestani, M.S.; Azimi, M.; Mahmodi, Z.; Mousavi, M.J.; Aslani, S. A comprehensive review on the treatment approaches of multiple sclerosis: Currently and in the future. Inflamm. Res. 2019, 68, 25-38. [CrossRef]

23. Shahrizaila, N.; Yuki, N. Guillain-Barré syndrome animal model: The first proof of molecular mimicry in human autoimmune disorder. J. Biomed. Biotechnol. 2011, 2011, 829129. [CrossRef]

24. Moise, L.; Beseme, S.; Tassone, R.; Liu, R.; Kibria, F.; Terry, F.; Martin, W.; De Groot, A.S. T cell epitope redundancy: Cross-conservation of the TCR face between pathogens and self and its implications for vaccines and autoimmunity. Expert Rev. Vaccines 2016, 15, 607-617. [CrossRef] [PubMed]

25. Matsoukas, J.; Apostolopoulos, V.; Mavromoustakos, T. Designing Peptide Mimetics for the Treatment of Multiple Sclerosis. Mini Rev. Med. Chem. 2005, 1, 273-282. [CrossRef] [PubMed]

26. Compston, A.; Coles, A. Multiple sclerosis. Lancet 2008, 372, 1502-1517. [CrossRef]

27. Davis, M.M.; Boniface, J.J.; Reich, Z.; Lyons, D.; Hampl, J.; Arden, B.; Chien, Y. Ligand Recognition By alpha beta T Cell Receptors. Annu. Rev. Immunol. 1998, 16, 523-544. [CrossRef] [PubMed]

28. Wootla, B.; Eriguchi, M.; Rodriguez, M. Is multiple sclerosis an autoimmune disease? Autoimmune Dis. 2012, 2012, 969657. [CrossRef] [PubMed]

29. Hare, B.J.; Wyss, D.F.; Osburne, M.S.; Kern, P.S.; Reinherz, E.L.; Wagner, G. Structure, specificity and CDR mobility of a class II restricted single- chain T-cell receptor. Nat. Struct. Biol. 1999, 6, 574-581. [CrossRef]

30. Rudolph, M.G.; Wilson, I.A. The specificity of TCR/pMHC interaction. Curr. Opin. Immunol. 2002, 14, 52-65. [CrossRef]

31. Rudolph, M.G.; Stanfield, R.L.; Wilson, I.A. How TCRS Bind MHCS, Peptides, And Coreceptors. Annu. Rev. Immunol. 2006, 24, 419-466. [CrossRef] [PubMed]

32. Lassmann, H. Axonal and neuronal pathology in multiple sclerosis: What have we learnt from animal models. Exp. Neurol. 2010, 225, 2-8. [CrossRef] [PubMed]

33. Reuter, E.; Gollan, R.; Grohmann, N.; Paterka, M.; Salmon, H.; Birkenstock, J.; Richers, S.; Leuenberger, T.; Brandt, A.U.; Kuhlmann, T.; et al. Cross-Recognition of a myelin peptide by CD8+ T cells in the CNS is not sufficient to promote neuronal damage. J. Neurosci. 2015, 35, 4837-4850. [CrossRef] [PubMed]

34. Madden, D.R. The Three-Dimensional Structure of Peptide-MHC Complexes. Annu. Rev. Immunol. 1995, 13, 587-622. [CrossRef]

35. Adams, E.J.; Luoma, A.M. The Adaptable Major Histocompatibility Complex (MHC) Fold: Structure and Function of Nonclassical and MHC Class I-Like Molecules. Annu. Rev. Immunol. 2013, 31, 529-561. [CrossRef]

36. Yannakakis, M.P.; Tzoupis, H.; Michailidou, E.; Mantzourani, E.; Simal, C.; Tselios, T. Molecular dynamics at the receptor level of immunodominant myelin oligodendrocyte glycoprotein 35-55 epitope implicated in multiple sclerosis. J. Mol. Graph. Model. 2016, 68, 78-86. [CrossRef]

37. Mouzaki, A.; Tselios, T.; Papathanassopoulos, P.; Matsoukas, I.; Chatzantoni, K. Immunotherapy for Multiple Sclerosis: Basic Insights for New Clinical Strategies. Curr. Neurovasc. Res. 2005, 1, 325-340. [CrossRef]

38. Tselios, T.; Daliani, I.; Deraos, S.; Thymianou, S.; Matsoukas, E.; Troganis, A.; Gerothanassis, I.; Mouzaki, A.; Mavromoustakos, T.; Probert, L.; et al. Treatment of experimental allergic encephalomyelitis (EAE) by a rationally designed cyclic analogue of myelin basic protein (MBP) epitope 72-85. Bioorg. Med. Chem. Lett. 2000, 10, 2713-2717. [CrossRef]

39. Tselios, T.; Apostolopoulos, V.; Daliani, I.; Deraos, S.; Grdadolnik, S.; Mavromoustakos, T.; Melachrinou, M.; Thymianou, S.; Probert, L.; Mouzaki, A.; et al. Antagonistic effects of human cyclic MBP87-99 altered peptide ligands in experimental allergic encephalomyelitis and human T-cell proliferation. J. Med. Chem. 2002, 45, 275-283. [CrossRef] 
40. Ntountaniotis, D.; Vanioti, M.; Kordopati, G.G.; Kellici, T.F.; Marousis, K.D.; Mavromoustakos, T.; Spyroulias, G.A.; Golic Grdadolnik, S.; Tselios, T.V. A combined NMR and molecular dynamics simulation study to determine the conformational properties of rat/mouse 35-55 myelin oligodendrocyte glycoprotein epitope implicated in the induction of experimental autoimmune encephalomyelitis. J. Biomol. Struct. Dyn. 2017, 35, 1559-1567. [CrossRef]

41. Mantzourani, E.D.; Platts, J.A.; Brancale, A.; Mavromoustakos, T.M.; Tselios, T.V. Molecular dynamics at the receptor level of immunodominant myelin basic protein epitope 87-99 implicated in multiple sclerosis and its antagonists altered peptide ligands: Triggering of immune response. J. Mol. Graph. Model. 2007, 26, 471-481. [CrossRef] [PubMed]

42. Willcox, B.E.; Gao, G.F.; Wyer, J.R.; Ladbury, J.E.; Bell, J.I.; Jakobsen, B.K.; Van der Merwe, P.A. TCR binding to peptide-MHC stabilizes a flexible recognition interface. Immunity 1999, 10, 357-365. [CrossRef]

43. Matsoukas, J.; Apostolopoulos, V.; Kalbacher, H.; Papini, A.M.; Tselios, T.; Chatzantoni, K.; Biagioli, T.; Lolli, F.; Deraos, S.; Papathanassopoulos, P.; et al. Design and synthesis of a novel potent myelin basic protein epitope 87-99 cyclic analogue: Enhanced stability and biological properties of mimics render them a potentially new class of immunomodulators. J. Med. Chem. 2005, 48, 1470-1480. [CrossRef] [PubMed]

44. Emmanouil, M.; Tseveleki, V.; Triantafyllakou, I.; Nteli, A.; Tselios, T.; Probert, L. A cyclic altered peptide analogue based on myelin basic protein 87-99 provides lasting prophylactic and therapeutic protection against acute experimental autoimmune encephalomyelitis. Molecules 2018, 23, 304. [CrossRef] [PubMed]

45. Spyranti, Z.; Dalkas, G.A.; Spyroulias, G.A.; Mantzourani, E.D.; Mavromoustakos, T.; Friligou, I.; Matsoukas, J.M.; Tselios, T.V. Putative bioactive conformations of amide linked cyclic myelin basic protein peptide analogues associated with experimental autoimmune encephalomyelitis. J. Med. Chem. 2007, 50, 6039-6047. [CrossRef] [PubMed]

46. Deraos, G.; Chatzantoni, K.; Matsoukas, M.T.; Tselios, T.; Deraos, S.; Katsara, M.; Papathanasopoulos, P.; Vynios, D.; Apostolopoulos, V.; Mouzaki, A.; et al. Citrullination of linear and cyclic altered peptide ligands from myelin basic protein (MBP87-99) epitope elicits a Th1 polarized response by T cells isolated from multiple sclerosis patients: Implications in triggering disease. J. Med. Chem. 2008, 51, 7834-7842. [CrossRef] [PubMed]

47. Matsoukas, J.; Apostolopoulos, V.; Lazoura, E.; Deraos, G.; Matsoukas, M.-T.; Katsara, M.; Tselios, T.; Deraos, S. Round and Round we Go: Cyclic Peptides in Disease. Curr. Med. Chem. 2006. [CrossRef]

48. Tzakos, A.G.; Fuchs, P.; Van Nuland, N.A.J.; Troganis, A.; Tselios, T.; Deraos, S.; Matsoukas, J.; Gerothanassis, I.P.; Bonvin, A.M.J.J. NMR and molecular dynamics studies of an autoimmune myelin basic protein peptide and its antagonist: Structural implications for the MHC II (I-A u)-peptide complex from docking calculations. Eur. J. Biochem. 2004, 271, 3399-3413. [CrossRef]

49. Wraith, D.C.; Smilek, D.E.; Mitchell, D.J.; Steinman, L.; McDevitt, H.O. Antigen recognition in autoimmune encephalomyelitis and the potential for peptide-mediated immunotherapy. Cell 1989, 59, 247-255. [CrossRef]

50. Lee, C.; Liang, M.N.; Tate, K.M.; Rabinowitz, J.D.; Beeson, C.; Jones, P.P.; McConnell, H.M. Evidence that the autoimmune antigen myelin basic protein (MBP) Ac1-9 binds towards one end of the major histocompatibility complex (MHC) cleft. J. Exp. Med. 1998, 187, 1505-1516. [CrossRef]

51. He, X.L.; Radu, C.; Sidney, J.; Sette, A.; Ward, E.S.; Garcia, K.C. Structural snapshot of aberrant antigen presentation linked to autoimmunity: The immunodominant epitope of MBP complexed with I-Au. Immunity 2002, 17, 83-94. [CrossRef]

52. Fugger, L.; Liang, J.; Gautam, A.; Rothbard, J.B.; McDevitt, H.O. Quantitative analysis of peptides from myelin basic protein binding to the MHC class II protein, I-A(u), which confers susceptibility to experimental allergic encephalomyelitis. Mol. Med. 1996, 2, 181-188. [CrossRef] [PubMed]

53. Metzler, B.; Wraith, D.C. Inhibition of experimental autoimmune encephalomyelitis by inhalation but not oral administration of the encephalitogenic peptide: Influence of MHC binding affinity. Int. Immunol. 1993, 5, 1159-1165. [CrossRef] [PubMed]

54. Laimou, D.; Lazoura, E.; Troganis, A.N.; Matsoukas, M.T.; Deraos, S.N.; Katsara, M.; Matsoukas, J.; Apostolopoulos, V.; Tselios, T.V. Conformational studies of immunodominant myelin basic protein 1-11 analogues using NMR and molecular modeling. J. Comput. Aided. Mol. Des. 2011, 25, 1019-1032. [CrossRef]

55. Spyranti, Z.; Tselios, T.; Deraos, G.; Matsoukas, J.; Spyroulias, G.A. NMR structural elucidation of myelin basic protein epitope 83-99 implicated in multiple sclerosis. Amino Acids 2010, 38, 929-936. [CrossRef] 
56. Mantzourani, E.; Mavromoustakos, T.; Platts, J.; Matsoukas, J.; Tselios, T. Structural Requirements for Binding of Myelin Basic Protein (MBP) Peptides to MHC II: Effects on Immune Regulation. Curr. Med. Chem. 2005, 12, 1521-1535. [CrossRef]

57. Mantzourani, E.D.; Tselios, T.V.; Grdadolnik, S.G.; Platts, J.A.; Brancale, A.; Deraos, G.N.; Matsoukas, J.M.; Mavromoustakos, T.M. Comparison of proposed putative active conformations of myelin basic protein epitope 87-99 linear altered peptide ligands by spectroscopic and modelling studies: The role of positions 91 and 96 in T-cell receptor activation. J. Med. Chem. 2006, 49, 6683-6691. [CrossRef]

58. Mantzourani, E.D.; Tselios, T.V.; Grdadolnik, S.G.; Brancale, A.; Platts, J.A.; Matsoukas, J.M.; Mavromoustakos, T.M. A putative bioactive conformation for the altered peptide ligand of myelin basic protein and inhibitor of experimental autoimmune encephalomyelitis [Arg91, Ala96] MBP87-99. J. Mol. Graph. Model. 2006, 25, 17-29. [CrossRef]

59. Mantzourani, E.; Laimou, D.; Matsoukas, M.; Tselios, T. Peptides as Therapeutic Agents or Drug Leads for Autoimmune, Hormone Dependent and Cardiovascular Diseases. Antiinflamm. Antiallergy Agents Med. Chem. 2008, 7, 294-306. [CrossRef]

60. Mantzourani, E.D.; Blokar, K.; Tselios, T.V.; Matsoukas, J.M.; Platts, J.A.; Mavromoustakos, T.M.; Grdadolnik, S.G. A combined NMR and molecular dynamics simulation study to determine the conformational properties of agonists and antagonists against experimental autoimmune encephalomyelitis. Bioorg. Med. Chem. 2008, 16, 2171-2182. [CrossRef]

61. Martel, P.; Makriyannis, A.; Mavromoustakos, T.; Kelly, K.; Jeffrey, K.R. Topography of tetrahydrocannabinol in model membranes using neutron diffraction. BBA Biomembr. 1993, 1151, 51-58. [CrossRef]

62. Mavromoustakos, T.; Daliani, I. Effects of cannabinoids in membrane bilayers containing cholesterol. Biochim. Biophys. Acta Biomembr. 1999, 1420, 252-265. [CrossRef]

63. Mavromoustakos, T.; Theodoropoulou, E. A combined use of 13C-cross polarization/magic angle spinning, 13C-magic angle spinning and 31P-nuclear magnetic resonance spectroscopy with differential scanning calorimetry to study cannabinoid-membrane interactions. Chem. Phys. Lipids 1998, 92, 37-52. [CrossRef]

64. Mavromoustakos, T.; De-Ping, Y.; Broderick, W.; Fournier, D.; Makriyannis, A. Small angle X-ray diffraction studies on the topography of cannabinoids in synaptic plasma membranes. Pharmacol. Biochem. Behav. 1991, 40, 547-552. [CrossRef]

65. Mavromoustakos, T.; Yang, D.P.; Makriyannis, A. Topography of alphaxalone and $\Delta 16$-alphaxalone in membrane bilayers containing cholesterol. BBA Biomembr. 1994, 1194, 69-74. [CrossRef]

66. Mavromoustakos, T.; Yang, D.P.; Makriyannis, A. Small angle X-ray diffraction and differential scanning calorimetric studies on O-methyl-(-)- $\triangle 8$-tetrahydrocannabinol and its $5^{\prime}$ iodinated derivative in membrane bilayers. BBA Biomembr. 1995, 1237, 183-188. [CrossRef]

67. Mavromoustakos, T.; Yang, D.P.; Makriyannis, A. Effects of the anesthetic steroid alphaxalone and its inactive $\triangle 16$-analog on the thermotropic properties of membrane bilayers. A model for membrane perturbation. BBA Biomembr. 1995, 1239, 257-264. [CrossRef]

68. Mavromoustakos, T.; Yang, D.P.; Makriyannis, A. Topography and thermotropic properties of cannabinoids in brain sphingomyelin bilayers. Life Sci. 1996, 59, 1969-1979. [CrossRef]

69. Mavromoustakos, T.; Theodoropoulou, E.; Papahatjis, D.; Kourouli, T.; Yang, D.P.; Trumbore, M.; Makriyannis, A. Studies on the thermotropic effects of cannabinoids on phosphatidylcholine bilayers using differential scanning calorimetry and small angle X-ray diffraction. Biochim. Biophys. Acta Biomembr. 1996, 1281, 235-244. [CrossRef]

70. Mavromoustakos, T.; Theodoropoulou, E.; Yang, D.P. The use of high-resolution solid-state NMR spectroscopy and differential scanning calorimetry to study interactions of anaesthetic steroids with membrane. Biochim. Biophys. Acta Biomembr. 1997, 1328, 65-73. [CrossRef]

71. Mavromoustakos, T.; Papahatjis, D.; Laggner, P. Differential membrane fluidization by active and inactive cannabinoid analogues. Biochim. Biophys. Acta Biomembr. 2001, 1512, 183-190. [CrossRef]

72. Koukoulitsa, C.; Durdagi, S.; Siapi, E.; Villalonga-Barber, C.; Alexi, X.; Steele, B.R.; Micha-Screttas, M.; Alexis, M.N.; Tsantili-Kakoulidou, A.; Mavromoustakos, T. Comparison of thermal effects of stilbenoid analogs in lipid bilayers using differential scanning calorimetry and molecular dynamics: Correlation of thermal effects and topographical position with antioxidant activity. Eur. Biophys. J. 2011, 40, 865-875. [CrossRef] [PubMed] 
73. Stern, J.N.H.; Illés, Z.; Reddy, J.; Keskin, D.B.; Fridkis-Hareli, M.; Kuchroo, V.K.; Strominger, J.L. Peptide 15-mers of defined sequence that substitute for random amino acid copolymers in amelioration of experimental autoimmune encephalomyelitis. Proc. Natl. Acad. Sci. USA 2005, 102, 1620-1625. [CrossRef] [PubMed]

74. Kant, R.; Pasi, S.; Surolia, A. Homo- $\beta$-amino acid containing MBP(85-99) analogs alleviate experimental autoimmune encephalomyelitis. Sci. Rep. 2015, 3, 8205. [CrossRef]

75. Yannakakis, M.P.; Simal, C.; Tzoupis, H.; Rodi, M.; Dargahi, N.; Prakash, M.; Mouzaki, A.; Platts, J.A.; Apostolopoulos, V.; Tselios, T.V. Design and synthesis of non-peptide mimetics mapping the immunodominant myelin basic protein (MBP83-96) epitope to function as T-cell receptor antagonists. Int. J. Mol. Sci. 2017, 18, 1215. [CrossRef]

76. Karin, N.; Mitchell, D.J.; Brocke, S.; Ling, N.; Steinman, L. Reversal of experimental autoimmune encephalomyelitis by a soluble peptide variant of a myelin basic protein epitope: T cell receptor antagonism and reduction of interferon $\gamma$ and tumor necrosis factor $\alpha$ production. J. Exp. Med. 1994, 180, 2227-2237. [CrossRef]

77. Katsara, M.; Matsoukas, J.; Deraos, G.; Apostolopoulos, V. Towards immunotherapeutic drugs and vaccines against multiple sclerosis. Acta Biochim. Biophys. Sin. 2008, 40, 636-642. [CrossRef]

78. Aharoni, R.; Teitelbaum, D.; Arnon, R.; Sela, M. Copolymer 1 acts against the immunodominant epitope 82-100 of myelin basic protein by $\mathrm{T}$ cell receptor antagonism in addition to major histocompatibility complex blocking. Proc. Natl. Acad. Sci. USA 1999, 96, 634-639. [CrossRef]

79. Mohammadi-Milasi, F.; Mahnam, K.; Shakhsi-Niaei, M. In silico study of the association of the HLA-A*31:01 allele (human leucocyte antigen allele 31:01) with neuroantigenic epitopes of PLP (proteolipid protein), MBP (myelin basic protein) and MOG proteins (Myelin oligodendrocyte glycoprotein) for studying t. J. Biomol. Struct. Dyn. 2020, 1-17. [CrossRef]

(C) 2020 by the authors. Licensee MDPI, Basel, Switzerland. This article is an open access article distributed under the terms and conditions of the Creative Commons Attribution (CC BY) license (http://creativecommons.org/licenses/by/4.0/). 